\title{
THE NON STANDARD ENGLISH USED BY WOMEN IN THE HELP MOVIE
}

\author{
Aal Inderajati ${ }^{1}$, Ubaidillah ${ }^{2}$
}

Sunan Kalijaga State Islamic University, Yogyakarta, Indonesia

(1aal.inderajati@gmail.com; ${ }^{2}$ ubaidillah@uin-suka.ac.id)

Received: $30^{\text {th }}$ September 2016; Revised: $10^{\text {th }}$ October 2016; Accepted: $20^{\text {th }}$ December 2016

\section{ABSTRACT}

This research discusses the grammatical features of Non-Standard English that is used by women characters in The Help movie and also the factors that influence it. The discussion in this research uses the theory from Trudgill (1999) and Holmes (1992). Further, SPEAKING formula proposed by Dell Hathaway Hymes (1974) is also used to determine the factors that influence the use of Non-Standard English. The study found five features of non-standard English used by women characters; they are missing auxiliary verbs, construction words, grammatical mistakes, wrong pronouns, and double negatives. Those features were found in the 108 data or conversations. The researcher analyzed those features through SPEAKING formula to find the factors. The factors which affect the use of non-standard English are Setting and Scene, Participants, Ends, and Genre. Moreover, Participants is the factor that mostly influences the use of Non-Standard English by women in The Help movie.

Key Words: black women; non-standard English; sociolinguistics

\section{ABSTRAK}

Dalam penelitian ini akan dibahas tentang fitur-fitur gramatikal bahasa Inggris non-standard yang digunakan oleh karakter wanita dalam film The Help dan juga faktor yang mempengaruhi penggunaannya. Pembahasan dalam penelitian ini menggunakan teori dari Trudgill dan Holmes. Disamping itu, teori SPEAKING yang dikemukakan oleh Dell Hathaway Hymes juga akan digunakan untuk mengetahui faktor yang mempengaruhi penggunaan bahasa Inggris non-standard tersebut. Dari hasil analisis, peneliti menemukan lima fitur bahasa Inggris non-standard yang digunakan oleh karakter wanita; fitur tersebut yaitu missing auxiliary verb, construction words, grammatical mistakes, wrong pronoun, dan double negative. Faktor yang mempengaruhi penggunaan bahasa nonstandard ialah Setting and Scene, Participants, Ends, dan Genre. Participants adalah faktor yang paling banyak mempengaruhi penggunaan bahasa Inggris nonstandard oleh karakter wanita dalam film The Help.

Kata Kunci: wanita kulit hitam, bahasa Inggris non-standard, sosiolinguistik

\section{Kata Kunci:}

How to Cite: Inderajati, A. Ubaidillah. (2016). The Non Standard English Used by Women in the Help Movie. IJEE (Indonesian Journal of English Education), 3(2), 106-122 doi:10.15408/ijee.v3i2.5509.

Permalink/DOI: http:/ /dx.doi.org/10.15408/ijee.v3i2.5509 


\section{INTRODUCTION}

Language is a set of words that have meaning. Santoso (1990) stated that language is a communication means generated and said consciuously by the important part of the human being's body . People use language as a communication device. As a means of communication, language cannot be saparated from social situations. Language always changes to suit the times and also life. In the daily life, language is a social phenomenon that shows the relationship between people through conversation.

Sociolinguistics is one of the linguistics branches. According to Holmes (1992), sociolinguistics is the linguistic domain that discusses the relationship between language and society . Sociolinguists also try to explain the relation between language and society. The sociolinguists explain some of the factors that influence the differences of language used by people. These differences are also a result of their environment or social contexts. Someone tends to put him or herself in a different language use for each different social condition. In sociolinguistics, it is known as language variations.

Trudgill (1999) explained that Standard and Non-Standard are not a language, but they are the variety of English language. According to Widarso (1994), Standard English, as a language variety, is divided into two forms: formal and informal. The formal form of Standard English is used for formal text like business letter, graduating paper, or discourse, and also for formal conversation like in a speech, seminar or panel discussion. On the other hand, the informal form is mostly used in daily conversation and it is also called as colloquialism. Here is the example of differences between formal and informal form of Standard English:

Formal : If I were you, I would accept it.

Informal: If I was you, I would accept it

Non-Standard English is one of language varieties which do not have any form. Widarso (1994) explained that Non-Standard English is commonly used by those who are lack of education. He also explains that Non-Standard English is different from the informal form. According to him, the informal form is used by almost all of educated people, but Non-Standard English is only used by people who are lazy to study and lack of education (1994). Indeed, the differences between Non-Standard and informal form can be seen through people who use it. If it is used by an educated man or woman, 
it is an informal form. If it is used by an uneducated man or woman, it is nonstandard.

Most people tend to use language variation to show their social status. Usually, the Standard English is used by people who have high social status. It is like people who work in a big company and have high salary. Then the Non-Standard English tend to be used by people who have low social status. In this case, Standard English is also mostly used by women. Holmes (1992) stated that "some linguists have suggested that women use more standard speech forms than men because they are more status-conscious than men" (p. 171). However, some women do not use standard language; the example is African Americans or Afro America women who use Black English. African Americans, also refers to Black Americans or Afro-Americans, is an ethnic group of citizens or residents of the United States with total or partial ancestry from any of native populations of Sub-Saharan Africa. The term may also be used to include only those individuals who are descended from African slaves.

Holmes (1992) said that Black English is heard especially in the northern cities of the United States. One of its most distinctive features is the complete absence of the copula verb be in some social and linguistic context. In most speech contexts, speakers of Standard English use shortened or reduced forms of the verb be. In other words, people do not usually say She is very nice but rather She's very nice. They reduce or contract the is to $s$.

On the other hand, a tribe is one of the social markers that shows the language use. People who come from the same tribe tends to use the language of their tribe, but they will change their language when meeting with other people from different tribes. Similar to the black community in America, they can be distinguished from other American society not only through their physical appearance, but also through the language they use. From this language, they try to maintain their ethnicity as black people.

Based on the phenomenon above, the problem addressed is the influence of ethnicity and social class in The Help movie. The differences are easy to find in their daily conversation especially differences in grammatical features. There are many differences in grammatical features between black and white people. Widarso (1994) stated that the most non-standard English commonly used is ain't and another distinctive grammatical feature of non-standard English is the use of 
double negative. Here is the example of the differences:

\section{Non-Standard English}

Jessie ain't been here.

Jessie hasn't been here.

\section{Standard English}

We ain't going nowhere.

We aren't going anywhere.

The first example of NonStandard English is shown by the use of the word ain't; the word ain't is the most non-standard English use. Compared to it, the Standard English does not use the word ain't but it becomes hasn't. The second example of Non-Standard English also shows the use of word ain't and no at the same time. It belongs to double negative as Holmes explained and this grammatical features exactly doest not follow the standard rule. In Standard English, the use of ain't and no is changed into the word aren't and any. From those cases, the language differences between White and Black People in America become one of the interesting issues to examine. Theoretically, this research will give an understanding to the readers about the features of Non-Standard English that show people's social status. Specifically, this research can be one of the examples in analyzing language used by American people.
Practically this research can give contributions to some people including the lecturers, students, and all of the readers.

1. For the lecturers, this research study can be a reference in sociolinguistics, especially about the social class differences through language use.

2. For the students, this research study can give a better understanding of how to apply Dell Hymes's SPEAKING approach.

3. For other researchers, this research study can be a reference to conduct further research.

4. For all of the readers, this research study can give information about variation of Non-Standard English in American society.

The object in this research study is The Help movie which was released in 2011. It was directed and written by Tate Taylor. It was adapted from Kathryn Stockett's 2009 novel with the same title. This movie exposes the differences of social class between White American and Afro American. The differences can also be found in their conversation. White Americans tend to use Standard English in their conversation and Afro Americans tend 
to use Non-Standard English. However, in some conversations White American also uses non-standard English. It is interesting to analyze this phenomenon because according to Holmes (1992), the Non-Standard English is commonly used by men, but in this movie, women also use non-standard in their conversation.

The purpose of this study is to describe the situation of how languages, in this case non-standard English, can show different social status. On the other hand, this study explains the important factors that influence the Non-Standard English used by women. This study focuses on the language used by some women characters. The eight idiosyncrasies or grammatical features of Standard English from Trudgill (1999) and NonStandard English grammar by Holmes (1992) are used as the main theories. Then SPEAKING theory from Dell Hymes are used to analyze the data as supporting theory, to know Setting, Participants, Ends, Acts, Keys, Instruments, Norms, and Genres in utterances. The result of the study will show the language used by those characters according to SPEAKING theory. Moreover, this research will give some benefits for the readers about understanding the Non-Standard English.
From the background of study above, it is clear that the analysis deals with language in social class. Concerning the interest of the issue, the research questions are: 1) How are the features of Non-Standard English used by women characters in The Help movie? 2) What are the important factors that influence the features?

\section{METHOD}

This research was conducted by using a qualitative method. The type of this research was a library research which analyzes the text. The data sources of this research were The Help movie. This research consisted of main data and supporting data. The main data for this research were the conversation or utterances containing non-standard English. Then the supporting data were the context of those utterances to see the purpose of the characters in using the nonstandard English in The Help movie. The data of this research were collected from The Help movie by document technique.

In collecting the data, the researcher took some steps. The first was watching The Help movie. The second was collecting the non-standard English used by black women characters. Then the last was listing the features of Non-Standard English based 
on the theory from Trudgill and Holmes.

In analyzing the data, the researcher divided the analysis into two kinds. The first is analyzing the classified data based on sociolinguistics. It consists of analyzing the nonstandard English. The next was finding the relationship of the non-standard English that is used by women characters using SPEAKING theory. SPEAKING itself is acronym of Setting and Scene, Participants, Ends, Act Sequence, Key, Instrumentalities, Norm, and Genre. According to Hymes, The Setting and Scene (S) of speech are important. Setting refers to the time and place, i.e., the concrete physical circumstances in which speech takes place. Scene refers to the abstract psychological setting, or the cultural definition of the occasion. The Participants (P) include various combinations of speaker-listener, addressor-addressee, or senderreceiver. They generally fill certain socially specified roles. Ends (E) refers to the conventionally recognized and expected outcomes of an exchange as well as to the personal goals that participants seek to accomplish on particular occasions. Act sequence (A) refers to the actual form and content of what is said: the precise words used, how they are used, and the relationship of what is said to the actual topic at hand. Key $(\mathrm{K})$, the fifth term, refers to the tone, manner, or spirit in which a particular message is conveyed: lighthearted, serious, precise, pedantic, mocking, sarcastic, pompous, and so on. Instrumentalities (I) refers to the choice of channel, e.g., oral, written, or telegraphic. Norms of interaction and interpretation $(\mathrm{N})$ refers to the specific behaviors and properties that attach to speaking. Genre (G), the final term, refers to clearly demarcated types of utterance (Hymes, 1974, 52-62).

It will also be used to find out the factors that is influence the nonstandard English used by women characters.

\section{FINDINGS AND DISCUSSION}

From all the conversation in the movie, there are 112 data containing five features of non-standard English used by the characters in The Help movie. It can be seen in the table below:

Table 1. Expression Features of NonStandard English

\begin{tabular}{lll}
\hline $\begin{array}{l}\text { Features of Non- Frequency } \\
\text { Standard English }\end{array}$ & $\begin{array}{l}\text { Percentage } \\
(\%)\end{array}$ \\
\hline $\begin{array}{l}\text { Missing/Lacking } \\
\text { Auxiliary Verb }\end{array}$ & 27 & $24.1 \%$ \\
Construction Words & 55 & $49.1 \%$ \\
$\begin{array}{l}\text { Grammatical } \\
\text { Mistakes }\end{array}$ & 15 & $13.3 \%$ \\
Wrong Pronoun & 6 & $5.3 \%$ \\
Double Negative & 9 & $8.0 \%$ \\
\hline
\end{tabular}


Based on the table above, it can be seen that the data found in the movie show five features of Non-standard English. Those features are mostly used by Black women in The Help movie. From the table, the feature of construction words appears 55 times or $49.1 \%$. The feature of construction words is the feature that is mostly appeared and used by the women characters in The Help movie.

To find out the factors that influence the features of non-standard English used by the women characters in the movie, the researcher uses SPEAKING theory proposed by Dell Hymes. By using this theory, the factors that influence the features can be clearly understood. The analysis is divided based on the features used by the women characters in the movie. The analysis also shows the differences of the using of each feature.

\section{The Use of Construction Words}

The researcher finds 55 conversation containing the use of construction words in The Help movie. 10 data belong to the construction words that are used by white people and 45 data belong to the construction words that are used by black people. The construction words are divided into four forms of construction words. They are gonna, gotta, ain't, and lotto.
From the 55 data, there are 8 data belonged to the using of gotta, 34 data belonged to the using of gonna, 10 data belonged to the using of ain't, 2 data belonged to the using of $y^{\prime}$ all, and only 1 data that using lotto.

\section{The Differences Use of Word "gonna"}

White and Black people use the same construction of gotta, ain't, and lotto. However, the use of gonna is different between white and black people. Here is the analysis of the using of word gonna:

Charlotte Phelan: You're gonna look beautiful on your date tonight.

Eugenia Skeeter: I can feel hope in your fingers. (datum 1)

This is an evidence from the utterance of you're gonna look beautiful on your date tonight. The word 'gonna' is preceded by be verb are, that is the rule of Standard English used by white people. It can be seen that Charlotte Phelan uses construction words when speaking with her daughter. She does not use a formal form of the word gonna which is going to. The conversation above is a conversation of white people, Charlotte Phelan and Eugenia Skeeter. Charlotte's speech can be analyzed using SPEAKING methods proposed by Dell Hymes. 
Setting and Scene: The conversation takes place in the kitchen of Charlote Phelan's house. Skeeter will be going on a date with Stuart. She never goes on a date, so her mother helps her styling the hair. Her mother is very excited and she hopes that Skeeter's date will be going well.

Participants: There are two participants in this conversation, Skeeter and her mother, Charlotte Phelan. Both Skeeter and Charlote Phelan are white people.

Ends: The purpose of the conversation is that Skeeter's mom wants to help Skeeter for her dress and make up to go on a date. She also hopes that Skeeter has a boyfriend soon.

Act Sequences: The content of the conversation is Charlotte Phelan really proud of her daughter who looks beautiful and she hopes that Skeeter's date goes well. Actually, Skeeter already knows her mother's hopes.

Key: Data obtained from The Help movie shows that the way Charlotte Phelan expressed her hope to Skeeter in very excited expression. It is because she is happy to see Skeeter goes on a date.

Instrumentalities: This conversation is a verbal spoken directly by Skeeter's mother to Skeeter. These conversations include casual conversation although
Skeeter talks to her mother, she does not use formal language.

Norms: In this conversation, Skeeter looks upset and she answers her mother hopes with such a joke. However, her mother still has a big hope for Skeeter.

Genre: Speech of Charlotte Phelan is an explanation form. This is a form of declarative sentences as expressed directly. Charlotte explains to Skeeter that she is happy to see Skeeter going on a date and she hopes that Skeeter will find a husband as soon as possible.

From the SPEAKING explanation above, because of the situation is not a formal situation, Charlotte Phelan speaks to her daughter casually. In fact, the conversation happens when Charlotte Phelan helps Skeeter and it is a kind of small conversation between mother and daughter. From the sociolinguistic perspectives based on ethnicity, Charlotte Phelan uses a construction word as suggested by Holmes in his book An Introduction To Sociolinguistics. Charlotte is one of the white people in this movie and she uses a construction word gonna in her coversation. Hence, the first factor that influence the use of non-standard English is the setting and scene in the conversation. This conversation happened in the kitchen so it is make 
the situation include in casual conversation.

Comparing the use of word gonna, it is clearly different between black and white people. It shows in this movie in which black people do not follow the rule of Standard English by using the word gonna without any be verb before it. Besides, the white people use non-standard English by using be verb before the word gonna.

The grammatical forms of Blacks are clearly different from what are used by white people. This difference is in terms of who speaks as a symbol of their tribe. One of the linguistic forms different from Afro-American tribes is the removal of verbs copula be. Simplifying the consonants also a factor to distinguish between AfricanAmerican and White English (Holmes, 1992: 194).

\section{Missing of Auxiliary Verbs}

The researcher finds 27 data that contain the missing of auxiliary verbs in The Help movie; they are missing of auxiliary have, has, is, and are. There are 15 data belonged to the missing of auxiliary verb have, 5 data belonged to the missing of auxiliary has, 6 data belonged to the missing of auxiliary verb are, and 1 data belonged to the missing of auxiliary verb is. In The Help movie, only black people omit the verb in their speech. Here is the analysis of missing of auxiliary verb have used by black people:

Yule Ma: Me and my husband, we been saving for years to send them to Tougaloo. We're short about $\$ 75$ on one of the tuitions.

Mr. William: Whoo! I am late. I gotta get going. (datum 2)

The conversation above is an example of a conversation by Yule Mae as black people and her boss, Mr. William as white people. It can be seen that Yule May omits the auxiliary verb have when speaking with his Boss, Mr. William. The sentence we been saving should have an auxiliary verb have, so it will be a correct sentence based on grammatical rule. Here, Yule May's speech can be analyzed using SPEAKING methods proposed by Dell Hymes.

Setting and Scene: The conversation takes place in the dining room. Yule May prepares the breakfast for her boss in the dining room while asking to her boss.

Participants: there are three participants in this conversation, Yule May, Miss Hilly, and Mr William. Yule May is black people, both Miss Hilly and Mr William are white people. Yule May is a help who works in Mr William house. 
Ends: The purpose of the conversation above is Yule May tells her boss that her sons have been graduated from high school and she wants to send them to the college.

Act Sequences: The content in this conversation is Yule May wants to owe money of her boss, but her boss ignores it by answering that he is late to go to work.

Key: Data obtained from the The Help shows that the way Yule Mae asks to Mr. William is in the piteous manner.

Instrumentalities: This conversation is a verbal conversation spoken directly by Yule May to Mr. Wiliam. These conversations include formal conversation because as a maid, Yule May should speak with the standard rule to her boss.

Norms: in this conversation, Yule May looks polite when asking to owe some money to Mr. Wiliam (her boss). However, Mr. Wiliam ignores her by directly leaving and going to work.

Genre: the speech of Yule May is a request or offer form. This is a form of declarative sentences expressed directly. It is a request because Yule Mae asks to Miss Hilly for some money to pay the registration for the boys.

From the SPEAKING explanation above, Yule May is trying to be polite when speaking to her boss but her boss is ignoring her. However, as a servant, she should speak formally to her boss. She also should use the proper grammar since the situation is a kind of formal situation and she wants help from her boss. Hence, the first factor that influence the use of non-standard English is the participants in the conversation. Yule May is the maid who is working in Mr. William's house and she is a black people. Yue May does not have a high education so her utterance does not follow the standard english rule. The second factor is instrumentalities. It is clear if the maid wants her boss to help them, they should use the standard English.

From the conversation it can be concluded that black people omit the auxiliary verb in their speech. Yule Mae and Minny omit the auxiliary have in their speech. Trudgill explains that black people redundantly distinguishes between the preterite and past participle forms of many verbs, as in $I$ saw - I have seen, or I did - I have done, where they have forms like seen or done for both (1999: 125).

\section{Grammatical Mistake}

The researcher finds 15 data containing the grammatical mistake in The Help movie; it consists of the mistake of using verb do/does, are, were, 
and also the missing of $s$ in the end of singular subject and missing preposition. There are 3 data that belong to the mistake of using do, 6 data belonged to the mistake of missing $s, 4$ data belonged to the mistake of using are, 2 data belonged to the mistake of using were. The analysis is as follows:

Minny: Then she say, "Oh, Minny, I'm gonna give you a paid vacation." (datum 3)

The datum above is one of the dialogues by Minny. She is telling her story when working as a maid for white people. Here, Minny's speech is included into grammatical mistakes because she does not use a correct grammar. In her speech, the sentence "Then she say" does not have 's' in the end of the verb say. If Minny follows the rule of standard English, her sentence will be then she says. Here is one of the evidences that Minny as a Black woman does not follow the rule of standard English grammar. Minny's speech can be analyzed using SPEAKING :

Setting and Scene: This monologue takes place in the kitchen at Aibileen's house. Minny tries to imitate her last boss statement when her boss wants to pay her by a vacation.

Participants: there are three participants in this conversation:Minny,
Skeeter, and Aibileen. Minny and Aibeleen are black people and Skeeter is white people. Minny is doing a monologue while Skeeter and Aibeleen only listen to her.

Ends: the purpose of the conversation is that Minny is telling her story and her experience when she works as a maid.

Act Sequences: the content of this conversation is the story of the maid, Minny, who is working for white people.

Key: Data obtained from the film The Help shows that the way Minny tells her story is in the high tone.

Instrumentalities: This conversation is a verbal conversation spoken directly by Minny to skeeter and Aibileen. These conversations include casual conversation because they both know each other.

Norms: in this conversation, Minny looks polite and passionated when telling her story.

Genre: speech of Minny is a narrative form. This is a form of declarative sentences as expressed directly. Minny is directly saying this sentence in front of Aibileen and Skeeter to express her feeling.

From the SPEAKING explanation above, Minny is telling her story when she is working as a maid. The situation 
is not formal and Minny speaks casually to Aibileen and Skeeter. She speaks politely and in passionate way because she likes to talk about her experience in working for white people. In fact, the conversation is between black people and white people. From the sociolinguistic perspectives based on ethnicity, Minny uses Non-Standard English as suggested by Holmes (1992) . Minny is one of the Black people in this movie and she uses Non-Standard English by omitting $s$. Hence, the important factor that influences the use of Non-Standard English is the participants in the conversation. Minny is the maid who work for Miss Cellia and she is a black people. Minny does not have a high education so her utterance does not follow the standard english rule.

From the example, it can be known that the feature of grammatical mistakes is commonly used by women characters in The Help movie especially by Black women, Minny and Aibileen. Besides they are black women, they are also working as a maid in which they do not know the correct grammatical of English language.

\section{The Use of Wrong Pronoun}

Another mistakes or another kind of Non-Standard English is the use of wrong pronoun. Black people tend to use some improper pronouns. The researcher finds 6 data containing the misuse of pronoun in The Help movie; they are them and their. There are 5 data belonged to the using of their and only 1 data belonged to the using of them. In "The Help" movie, most of the mistakes are found in their monologue. The data below are the speech from Aibileen and Minny that will be analyzed using SPEAKING. The first datum is the dialogue from Aibileen:

Aibeelen: I know how to get them babies to sleep, stop crying and go in the toilet bow before their mamas even get out of bed in the morning. (datum 4)

From the monologue above, it could be seen that Aibileen uses the wrong pronoun in her speech. The phrase them babies should be their babies if Aibileen uses the correct grammar rule. However, instead of using their, Aibileen chooses to use them. Here is the SPEAKING analysis of Aibileen's speech:

Setting and Scene: This monologue takes place in the Mae mobly's bed room. Aibeleen feels that her boss does not care about her babies.

Participants: there is only one participant in this monologue, Aibeelen. Aibeelen is a black people.

Ends: The purpose is Aibeelen wants to describe her job. 
Act Sequences: The content of monologue above is about Aibeelen's experience as the help.

Key: Data obtained from the film The Help shows that the way Aibeelen is doing a monologue.

Instrumentalities: This conversation is a verbal conversation spoken directly by Aibeelen.

Norms: in this monologue, Aibeelen looks polite when she explains about her job.

Genre: speech of Aibileen is a narrative form. This is a form of declarative sentences expressed directly. Here, Aibileen tells her story when she becomes a servant and takes care of white baby.

From the SPEAKING explanation above, it can be seen that Aibileen is telling the story and her experience when being a help. She did many things including being a baby sitter and taking care of the house. She speaks casually because she tells her story. Hence, the first factor that influences the use of non-standard English is the participants in the conversation. Aibeleen is the maid and she is a black people. Aibeleen does not have a high education so her utterances do not follow the Standard English rule. The second factor is Setting. In this case, Aibeleen doing this monologue in Mae
Mobly bedroom. Through this monologue she shows that she is taking care of Mae Mobly who is a white baby of her boss.

From the conversation above, it can be seen that Black people use the wrong pronoun. It is proven by the use of they "Get back into they house" and "I know how to get them babies". Aibileen and Minny should use their instead of they as the pronoun. Holmes (1992) also explained that a different way of speaking also looks because they are a minority group. The differences include; the use of the plural, which is used as a form of me possessive pronoun I, my, me, and also the shape of dem for they, them, their. The function of this difference is as a symbol of their identity as ethnic minorities.

\section{The Use of Double Negative}

The researcher finds 9 data that contain be using of double negative in The Help movie. All of the data have the same form in which the speaker uses ain't and no at the same time. The use of double negative is also the characteristics of Black people. Unlike white people that only use one negative such as I don't like you, black people tend to use double negative as shown in the conversation below:

Miss Celia: I just want you to know I'm real grateful you're here. 
Minny: You gots plenty more to be grateful for than me. And look, now I ain't messing around no more. (datum 5)

The conversation above is the conversation between white and black people. Miss Celia is the new boss of Minny. From the conversation above, it could be seen that Minny uses the negative concord ain't but she also uses no in the end of her speech. Based on English grammatical rule, Minny does not need to use ain't and no at the same time. She can choose to use ain't or no such as I ain't messing around. Here, Minny's speech above can be analyzed using SPEAKING:

Setting and Scene: The conversation takes place in the Miss Celia's kitchen. Miss Celia is very happy about Minny who does work as her help. Minny also feels happy to work as Miss Celia's help.

Participants: there are two participants in this conversation, Miss Celia and Minny. Miss Celia is a white woman while Minny is a black woman.

Ends: The purpose of conversation above is that Minny wants Miss Celia knows that she will be working seriously and not doing any bad acts.

Act Sequences: The content of conversation above is both Miss Celia feels comfortable about Minny and Minny has the same feeling with her boss. Miss Celia and Minny enjoy each other as the boss and the help.

Key: Data obtained from the film The Help shows that the way Minny is in the light-hearted way.

Instrumentalities: The conversation above is a verbal conversation spoken directly by Minny to Miss Celia.

Norms: in this conversation, Minny looks polite when she says that she wants to work seriously.

Genre: the speech of Minny is an explanation form. This is a form of declarative sentences as expressed directly. Minny implicitly says that she does not want to get problems with her boss, especially white people. Thus, she wants to work seriously.

From the SPEAKING explanation above, it can be seen that Minny is giving a warning for Miss Celia. She tells her that even Miss Celia is happy to have Minny as a servant, Minny does not want to have any grateful feeling when working with white people. So, her opinion is told in casual language and she tells that she does not want to make any problem with white people even she hates all white people. Hence, the first factor that influences the use of Non-Standard English is the participants in the conversation. Minny is the maid working to Miss Cellia and she is a black woman. Minny does not 
have a high education so her utterance does not follow the standard english rule. The second factor is Ends. It influences the use of non-standard English because Minny says "I ain't messing around no more" in order to convince Miss Celia that she will work seriously.

The second datum for the using of double negative is the conversation between Aibileen and Minny as follows:

Aibeelen: We can't put that story in the book.

Minny: We ain't got no choice. (datum 6)

The conversation above is the conversation between Black women. From the conversation above, it could be known that Minny uses the negative concord ain't but she also uses no in the end of her speech. Based on English grammatical rule, Minny does not need to use ain't and no at the same time. She can choose to use ain't or no such as We ain't got choice or We got no choice. Here, Minny's speech above can be analyzed using SPEAKING:

Setting and Scene: The conversation takes place in the Aibeelen's kitchen. Aibeelen feels afraid if she put Minny's story in to the book.
Participants: there are two participants in this conversation, Minny, Aibeelen. Both Minny and Aibeleen are black women.

Ends: The purpose is that Minny wants Aibeelen to believe that the story about Miss Hilly will help them to get insurance.

Act Sequences: The content of conversation above is that Aibeleen says that they cannot put Minny's story into the book but Minny says that put her story in the book is the only choice.

Key: Data obtained from The Help shows that the way Minny asks Aibeelen to believe is in the serious tone.

Instrumentalities: This conversation is a verbal conversation spoken directly by Minny in responding to Aibeelen's statement. These conversations include in casual conversation because they both know each other.

Norms: in this conversation, Minny looks polite when telling the bad story about miss hilly and asking Aibileen to believe her.

Genre: the speech of Minny is a declarative form. This is a form of declarative sentences as expressed directly. Minny says her opinion directly to Aibileen to make her believe in Minny's opinion. She just wants to 
solve the problem and helps Skeeter to publish her book safely.

From the SPEAKING explanation above, it can be seen that Minny is telling her opinion about the book that Skeeter writes. She argues that by putting her story to the book, it will make the Black people safe. They would not get any threat from white people because of telling the truth about the reality working for white people because they do not treat well. Minny speaks in clear voice because she wants to make Aibileen believe in her opinion. She also uses double negative to emphasize her opinion.

Although the conversation is spoken in a casual way, Minny shows her seriousness through her statement. Hence, the first factor that influences the use of Non-Standard English is the participants in the conversation. Minny is the maid and she is a black woman. Minny does not have a high education so her utterance does not follow the Standard English rule. The second factor is scene. It can be known that scene from Minny's psychological setting believe that there are no other ways to do. Then, the third factor is Ends. It is because she believes about it, so she says the purpose to get the insurance.

In sociolinguistics perspective, both Minny and Aibileen is using double negative in their speech. Trudgill explained that Standard English does not permit double negation (negative concord). Aibileen and Minny tend to use ain't and no at the same time and it makes their speech improper. They should choose one of the negatives to avoid an ambiguity and wasted words.

\section{CONCLUSION AND SUGGESTION}

After analyzing the differences features of non-standard English used by the women characters in The Help movie, the researcher concludes several things.

From the 112 conversations containing the features of non-standard English, the researcher found five features of Non-Standard English used by women characters in The Help movie, namely missing/lacking auxiliary verb, construction words, grammatical mistakes, wrong pronoun, and double negative.

The features of missing verb used by the women character in the movie appear 27 times or $24.1 \%$, the feature of construction words appears 55 times or $49.1 \%$, the feature of grammatical mistakes appears for 15 times or 13.3\%, the feature of wrong pronoun appears for 6 times or $5.3 \%$, and the feature of double negative appears for 9 times or 
$8.0 \%$. The feature of construction words is the feature that is mostly appeared and used by the women characters in The Help movie. Moreover, it is the only feature that is used by white women in this movie.

From the SPEAKING analysis, the important factor that influences the use of Non-Standard English are Setting and Scene, Participants, Ends, and Genre in the conversation. Moreover, almost all of the data influenced by participants. From the participants in each conversation, it can also be known the factors that influenced the use of Non-Standard English are education, social class, and also tribe. People with lack education tend to use nonstandard because they lack of formal education. In this movie, the black people are the people who lack of education. They work as a help for white people since they were young. Therefore, they use non-standard language because they do not get a formal education about how to speak in formal and standard language, how to use the proper and good English, and how to speak to others properly.

Another factor that explains the participants is a low social class. It will also affect the use of language. The black people tend to use non-standard language because they never met other people except the black people and they never learn how to speak in proper grammar and standard language.

\section{REFERENCES}

Holmes, J. (1992). An introduction to sociolinguistics. New York: Longman Publishing.

Hymes, Dell. (1974) Language in Culture and Society (London: A Harper Int.Ltd.,

Santoso, K. B. (1990). Problematika Bahasa Indonesia. Jakarta: Rineka Cipta.

Trudgill, P. (1999). Standard English: The widening debate. London: Routledge.

Wardhaugh, R. (2006). An introduction to sociolinguistics ( $5^{\text {th }}$ ed.). Victoria: Blackwell.

Widarso, W. (1994). Bahasa Inggris. Yogyakarta: Kanisius. 